\title{
Damage Mechanisms in AISI 304 Borided Steel: Scratch and Daimler-Benz Adhesion Tests
}

\author{
German Anibal Rodríguez-Castro ${ }^{a *}$, Luis Fernando Jiménez-Tinoco ${ }^{a}$,
}

Juan Vicente Méndez-Méndez $z^{b}$ Israel Arzate-Vázquez, Alfonso Meneses-Amadora, Hugo Martínez-Gutiérrez $z^{b}$, Iván Campos-Silva ${ }^{a}$

\author{
${ }^{a}$ Grupo Ingeniería de Superficies, SEPI-ESIME, Instituto Politécnico Nacional, \\ U.P. Adolfo López Mateos, Zacatenco, México D.F., 07738, México \\ ${ }^{b}$ Centro de Nanociencias y Micro-Nano Tecnologías, Instituto Politécnico Nacional, \\ U.P. Adolfo López Mateos, Zacatenco, México D.F., 07738, Mexico
}

Received: August 30, 2015; Revised: October 21, 2015

\begin{abstract}
In this study, damage mechanisms in the $\mathrm{FeB} / \mathrm{Fe}_{2} \mathrm{~B}$ coatings formed on the surface of AISI 304 steel are determined by adhesion tests. First, the boriding of the AISI 304 steel was carried out through the powder-pack method at $1223 \mathrm{~K}$ in the range from 2-10 h of exposure time. After treatment, Berkovich depth-sensing indentation test were conducted; the result showed tensil and compressive residual stresses in the $\mathrm{FeB}$ and $\mathrm{Fe}_{2} \mathrm{~B}$, respectively. The adhesion of borided steels was evaluated by the Daimler-Benz Rockwell-C and scratch test. Based on the scratch tracks, the chipping was the predominant mechanism at 2 and $6 \mathrm{~h}$, with critical loads of 35 and $43 \mathrm{~N}$, respectively; while spalliation was determined at $27 \mathrm{~N}$ for $10 \mathrm{~h}$. Also, hertzian and tensil cracks, buckling and compressive delamination were determined in the AISI 304 borided steel by scanning electron microscope.
\end{abstract}

Keywords: boride layers, scratch test, residual stresses, damage mechanisms

\section{Introduction}

AISI 304 steel is a general purpose austenitic stainless steel. It has high ductility, excellent drawing, forming and spinning properties with lower susceptibility to intergranular corrosion and less carbide precipitation during welding in the heat-affected zone. Despite its resistance to corrosion of steel AISI 304, it is necessary to improve their performance in terms of wear and/or adhesion. A major disadvantage of austenitic steels is that they cannot be hardened by conventional treatments. However, the ability to change the surface properties of bulk materials by the use of surface coatings has opened up new and diverse applications in an endless number of technological areas ${ }^{1}$. There are several thermochemical treatments which alter the surface of a material changing its chemical composition and the microstructure thereof. Using thermochemical treatments, wear resistance can be improved, having a greater effect when the predominant phenomenon is the abrasive. Within these treatments, boriding is a surface modification, whereby boron is diffused into, and combines with, the substrate material resulting in the formation of iron borides. Depending on the temperature and time of the process, the chemical composition of the material and boron potential of the surrounding medium can form a single phase $\mathrm{Fe}_{2} \mathrm{~B}$ or double phase $\left(\mathrm{FeB} / \mathrm{Fe}_{2} \mathrm{~B}\right)$ with defined composition ${ }^{2-5}$. Boriding can be attained by different mediums as solid, liquid and gaseous. The boriding process can increase up to $2000 \mathrm{HV}$ surface hardness, improving the tribological properties of hardened components. Also, its hardness retention at elevated temperature, its corrosion

*e-mail: garodriguezc@ipn.mx resistance, and decrease in tendency to cold weld and reduction in the use of lubricants are noteworthy features ${ }^{6,7}$. The basic idea of coatings - having special properties on a substrate surface that cannot be reached by the substrate material itself - is necessarily dependent on the adhesion between substrate and coating. The test procedure that is best known and most used for adhesion measuring of hard coatings on steel substrates is the scratch test. Allaoui et al. ${ }^{8}$ studied coating/substrate system adhesion by scratches developed in borided XC38 steel (medium carbon steel) by immersion in molten salts, concluding that the best performance was obtained on a single-phase layer with critical load of $132 \mathrm{~N}$. Taktak $^{9}$ identified the delamination failure characteristics of boride-coated $\mathrm{Cr}$ based steels by Rockwell $\mathrm{C}$ adhesion test. The boriding was carried out using a slurry salt bath. The main finding was that adherence decreases with increasing temperature and process time. Adhesion decreases due to the increased thickness of the $\mathrm{FeB}$ phase and tensile residual stresses present therein.

In the present paper, $\mathrm{FeB} / \mathrm{Fe}_{2} \mathrm{~B}$ coatings developed on the surface of AISI 304 steel by pack boriding method (solid medium) are studied by two adhesion tests: a) Rockwell C adhesion test is used as a quality test for iron boride layer, and b) the scratch test to evaluate AISI 304 borided steel with incremental loads from 1 to $90 \mathrm{~N}$ for the set of experimental parameters of the boriding process. Damage caused by both tests was analyzed by a JEOL JSM-7800F scanning electron microscope. The mechanical properties and the effect of residual stresses of the borides layers on Berkovich depth sensing indentation at $50 \mathrm{mN}$ of load were evaluated. 


\section{Experimental Procedure}

\subsection{Power pack boriding process}

Samples of rectangular shape (19 and $6.35 \mathrm{~mm}$ of side and height, respectively) were mechanically polished with $\mathrm{SiC}$ sandpaper up 1500 grade. The polished surfaces were cleaned with acetone before boriding process. After, the samples were submitted to pack boriding process using Ekabor 2 as a boron-rich agent. The process was carried out at $1223 \mathrm{~K}$ over 2, 6 and 10 hours of exposure time. After completion of treatment, the container was removed from the heating muffle to cool down to room temperature. Following this, the borided samples were prepared metallographically for their characterization using GX51 Olympus equipment. The identification of phases was carried out on the top surface of boronized sample by X-ray diffractions using GBC MMA equipment with a $\mathrm{CuK} \alpha$ radiation at $\lambda=1.54 \mathrm{~A}$. In addition, an analysis was performed by Energy Dispersive $\mathrm{X}$-ray spectroscopy (EDS) to obtain an average value of the transition elements in the iron borides $\left(\mathrm{FeB}\right.$ and $\left.\mathrm{Fe}_{2} \mathrm{~B}\right)$ and diffusion zone. The dimensions of the tested areas were $6 \times 80 \mu \mathrm{m}$, approximately. The equipment used was the Quanta 3D FEG-FEI JSM7800 - JEOL.

\subsection{Berkovich depth-sensing indentation}

The microhardness profile of the boride layer was assessed with a Berkovich depth-sensing test using the CSM Indentation Tester (TTX-NHT) and following the recommendations of the ISO 14577 standard $^{10}$ in order to avoid the interaction between the stresses field of the indentations. The indentations were performed in cross section of the $\mathrm{FeB} / \mathrm{Fe}_{2} \mathrm{~B}$ layer at different distances from the surface using a load of $50 \mathrm{mN}$. At each distance, at least three indentations were made with load/unload rates of $200 \mathrm{mN} / \mathrm{min}$ and a dwell time of $10 \mathrm{sec}$. The hardness and Young's modulus were calculated using the Oliver and Pharr method, which consider the projected area of the Berkovich indenter and the contact depth of indentation ${ }^{11}$. In Figure 1 are shown the load-displacement curves obtained by Berkovich depth-sensing in both $\mathrm{FeB}$ and $\mathrm{Fe}_{2} \mathrm{~B}$ phases for $10 \mathrm{~h}$ of treatment. Moreover, the residual stresses during indentations on the $\mathrm{FeB} / \mathrm{Fe}_{2} \mathrm{~B}$ layer were estimated according to the model proposed by Chen et al. ${ }^{12,13}$ :

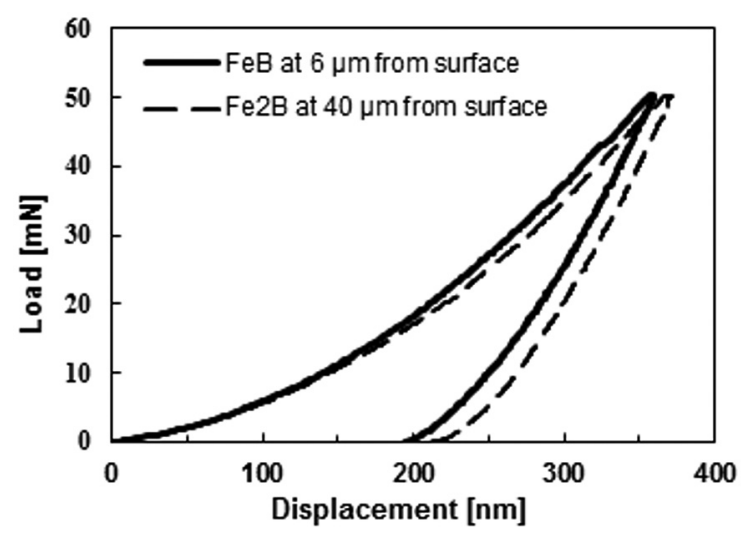

Figure 1. Load-displacement curves by depth sensing indentation using a load of $50 \mathrm{mN}$ in $\mathrm{FeB}$ and $\mathrm{Fe} 2 \mathrm{~B}$ phases formed on AISI 304 steel at $1223 \mathrm{~K}$ for $10 \mathrm{~h}$.

$$
\frac{F}{E h^{2}}=5.626\left(\frac{Y^{*}}{E}\right)^{0.5} \times\left\{1-\left[3.51\left(\frac{Y^{*}}{E}\right)^{0.5}+0.0032\left(\frac{Y^{*}}{E}\right)^{-0.5}\right]\left(\frac{\sigma_{r}}{Y^{*}}\right)\right\}
$$

Where $F$ is the applied load, $E$ is the Young's modulus, $h$ is the penetration depth, $\sigma_{y}$ is the residual stresses and $Y^{*}=(Y K)^{1 / 2} . \mathrm{K}$ is a strength coefficient given by Equation $2^{13}$.

$K=Y(E / Y)^{n}$

Where, $Y$ is the yield strength and $n$ is the strength hardening exponent.

\subsection{Adhesion tests}

The Daimler-Benz adhesion test is used as a destructive quality test for coating/substrate systems. This method causes layer damage adjacent to the boundary of the Rockwell indentation ${ }^{14}$. The damage around the indentation can be evaluated by microscopy and compared with a defined pattern of adhesion strength. The VDI standard ${ }^{15}$ defines the pattern of HFI to HF4 as an acceptable adhesion, and HF5 and HF6 as insufficient adhesion of the coating/substrate system ${ }^{15,16}$. Rockwell $\mathrm{C}$ tests were conducted by a durometer Albert using a load of $1471 \mathrm{~N}$. Ten indentations were carried out on the surface of AISI 304 borided steel for each treatment condition.

Scratch tests were carried out using Revetest Xpress commercial equipment (CSM Instrument) which senses the normal and tangential force. A $200 \mu \mathrm{m}$ radius Rockwell $\mathrm{C}$ diamond stylus was drawn across the coated surfaces under a normal load increased up to $90 \mathrm{~N}$. The Scratch test characterizes the superficial mechanical properties of AISI 304 borided steel, obtaining information such as adhesion, cohesion, damage mechanisms and critical loads. Six scratch tests were conducted for each of the boriding conditions with a loading rate of $18 \mathrm{~N} / \mathrm{min}$ and speed of $1.42 \mathrm{~mm} / \mathrm{min}$. Before the scratch tests, the roughness surface was verified by Mitutoyo Roughness tester. The surface roughness of the samples was determined in $\mathrm{Ra}=0.08 \mu \mathrm{m}$ as maximum value regardless of exposure time, complying with the requirement of ASTM C1624 ${ }^{17}$. The critical loads were attributed to the normal force and the occurrence of damage using the Equation 3.

$$
L_{C N}=\left[L_{R A T E} \cdot\left(\frac{L_{N}}{X_{R A T E}}\right)\right]+L_{S T A R T}
$$

Where, $L_{C N}, L_{R A T E}$ and $L_{N}$ are the critical scratch load (N), the loading rate $(\mathrm{N} / \mathrm{min})$ and the distance from the baseline of the scratch track to start point of the defined type of damage in the track (mm), respectively. $X_{R A T E}$ is the rate of horizontal displacement in the test $(\mathrm{mm} / \mathrm{min})$ and the $L_{\text {START }}$ is the preload stylus force established at the start of the test $(\mathrm{N})$.

\section{Results and Discussions}

\subsection{Boriding process}

The metallography of coating/substrate formed in AISI 304 borided steel for the three boriding conditions are shown in Figure 2. Commonly, in AISI 304 borided steel 
few pores or cracks are observed regardless of exposure time $^{18}$. Morphology of the boride layer is mainly caused by the alloying elements of AISI 304 steel; the nickel and chromium reduce the growth of the layer and dismish the degree of preferred orientation, decresing the saw-tooth morphology ${ }^{7}$. The patterns of X-ray diffraction (Figure 3) show the presence of $\mathrm{FeB}$ and $\mathrm{Fe}_{2} \mathrm{~B}$ phases which are well compacted. However, Figure 2c) shows a mixture of phases; the $\mathrm{FeB}$ phase is defined as a FeB-base phase since it generally contains high boron products disolved therein because it grows from the transformation of the $\mathrm{Fe} 2 \mathrm{~B}$ phase ${ }^{19}$.
According with EDS analysis (Figure 4), the FeB phase contains on average $13.5 \mathrm{wt}$. $\%$ and the $\mathrm{Fe}_{2} \mathrm{~B}$ contains $12.33 \mathrm{wt}$. $\%$ for Chromium. Furthermore, the nickel content decreases towards the outer part of the boride layer; it was determined a content of 4.75 and 6.85 wt. \% in the $\mathrm{FeB}$ and $\mathrm{Fe} 2 \mathrm{~B}$ phases, respectively. With increase in the chromium concentration in the substrate, the quantity of $(\mathrm{Fe}, \mathrm{Cr}) \mathrm{B}$ also increases in the surface layer ${ }^{20}$; hence, the high chromium content in the AISI 304 steel facilitates its mobility in the borides, compared with nickel whose presence is minor. Chromium tends to insert itself preferentially and systematically in the

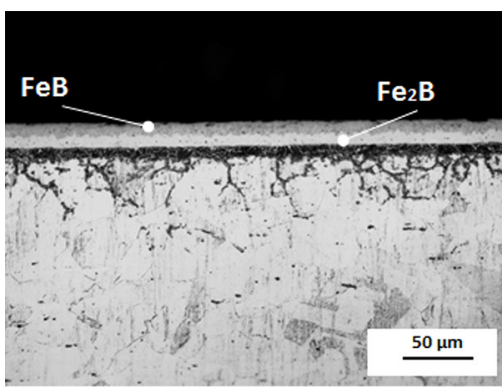

(a)

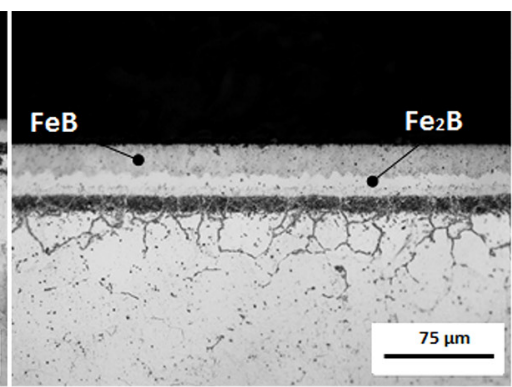

(b)

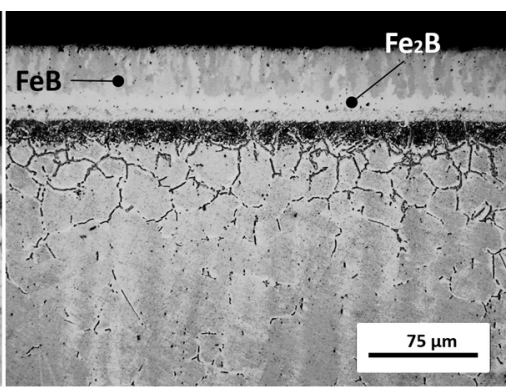

(c)

Figure 2. Micrography of boride layer formed on AISI 304 steel at $1223 \mathrm{~K}$ during different exposure time: (a) $2 \mathrm{~h}$, (b) $6 \mathrm{~h}$ and (c) $10 \mathrm{~h}$.

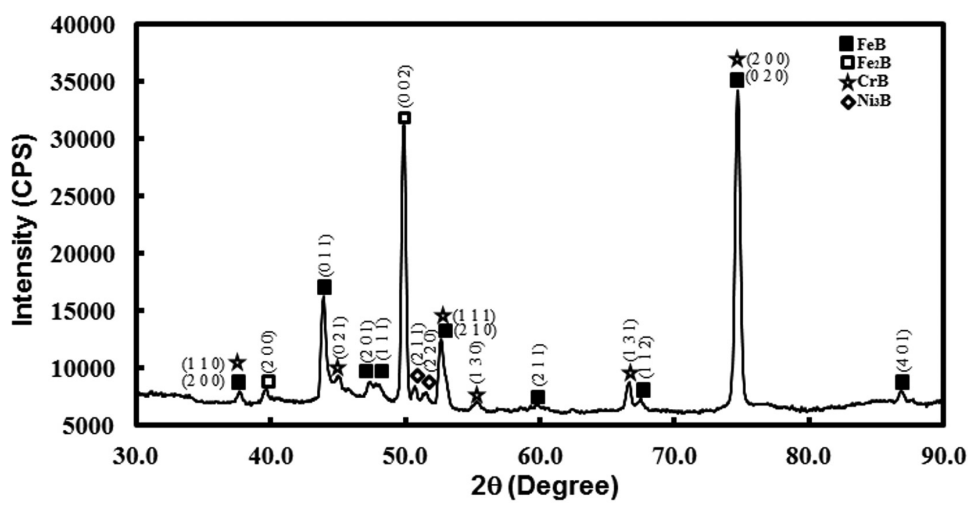

(a)

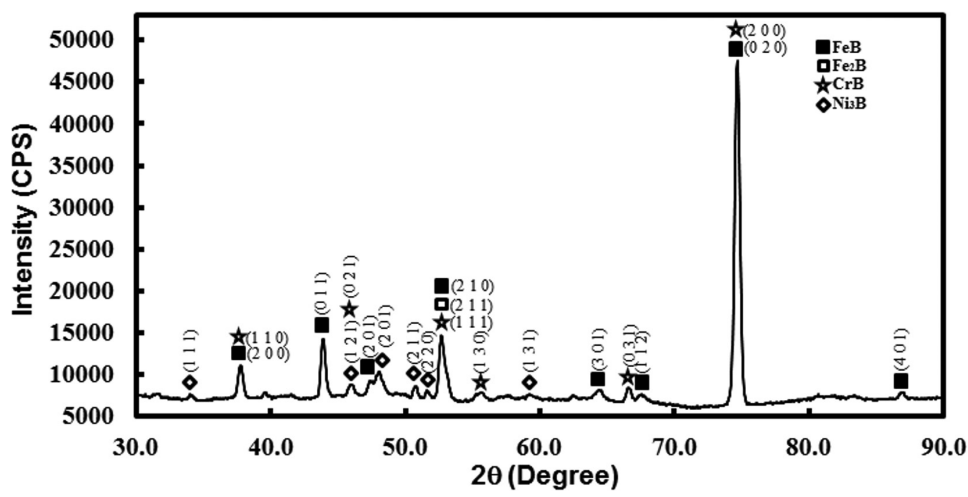

(b)

Figure 3. Patterns of X-ray diffraction on AISI 304 borided steel at $1223 \mathrm{~K}$, over (a) $2 \mathrm{~h}$ and (b) $10 \mathrm{~h}$ of exposure time. 


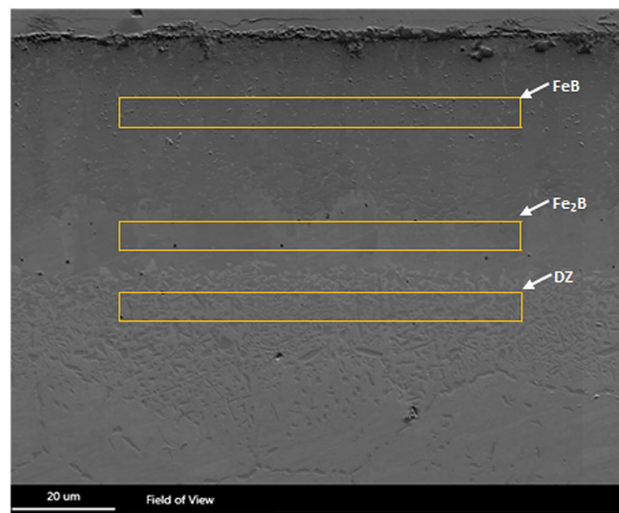

(a)

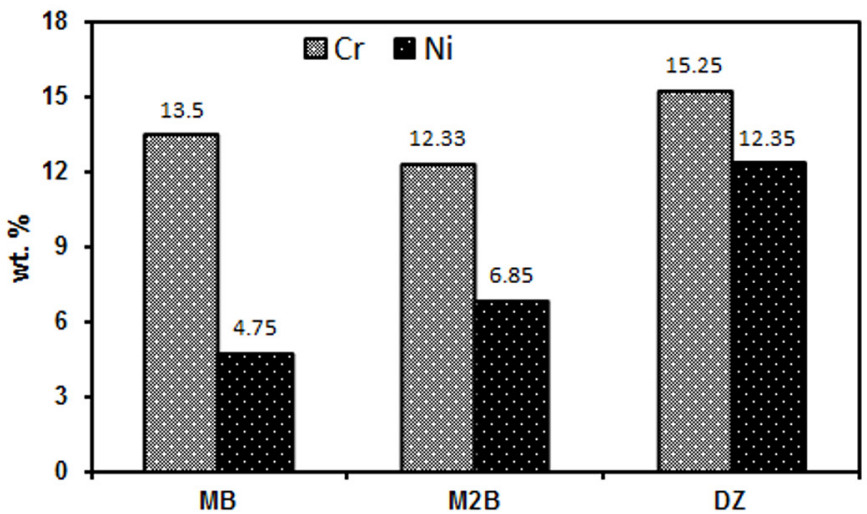

(b)

Figure 4. EDS analysis in AISI 304 borided steel at $1223 \mathrm{~K}$ for $10 \mathrm{~h}$ (a) analyzed areas in cross section $(6 \times 80 \mu \mathrm{m})$, (b) Histogram of composition (wt. \%) of $\mathrm{Cr}$ and $\mathrm{Ni}$.

(Fe, $\mathrm{Cr}) \mathrm{B}$ because the chromium have an atomic number lower than the iron ${ }^{21}$. In contrast, the diffusion of nickel in iron borides is difficult due to its atomic number is greater than iron and it inserts in the lowest boron content phase $(\mathrm{Fe} 2 \mathrm{~B})$. The presence of Ni-rich thin layer is confirmed below the Fe2B phase with a 12.35 wt. \%. The chromium concentration in the diffusion zone is greater than in the borides (15.25 wt.\%), confirming a Cr-rich zone formed by a thin layer and $\mathrm{Cr}$-precipitation in the grain boundaries as Rus et al. reported ${ }^{18}$. The presence of $\mathrm{Cr}_{2} \mathrm{O}$ is because no inert atmosphere was used during the boriding. The total layer thicknesses $\left(\mathrm{FeB}+\mathrm{Fe}_{2} \mathrm{~B}\right)$ were of 13.3, 30.2 and $44.4 \mu \mathrm{m}$ for 2, 6 and $10 \mathrm{~h}$ of exposure time with a maximum standard deviation of $4 \%$. The percentage of the FeB phase is $75 \%$ over the total thickness.

\subsection{Berkovich depth-sensing indentation}

In Figure 5, the results of hardness along the depth of the boride coatings are shown. The hardness value is dependent of the treatment time and the highest hardness is about $24 \mathrm{GPa}$ for $10 \mathrm{~h}$ of exposure time. The presence of chromium increases the hardness of the layers formed on steel AISI 304. This result is confirmed by the hardness achieved in different studies, where hardness ranges are between 1665-2440 for $\mathrm{FeB}$ phase and 1380 to $1740 \mathrm{Hv}$ for $\mathrm{Fe}_{2} \mathrm{~B}^{8}$. The hardness varies depending on the substrate composition manifesting the highest values in steels with alloying elements such as $\mathrm{Cr}, \mathrm{V}, \mathrm{W}$ and Mo. In the AISI 304 steel, Cr increases the hardness of the layer of iron borides obtained values close to $2.5 \mathrm{GPa}$. Hardness values decrease as the indentations are closer to substrate due to the stochiometric characteristic of the boride phases with constant boron concentration ${ }^{9,22}$. In Figure 6, the residual stresses obtained by Equation 1 are shown. All samples submitted to boriding presented a tensile stress stated in the $\mathrm{FeB}$, whilst in the $\mathrm{Fe}_{2} \mathrm{~B}$ the residual stresses are compressive. The residual stresses obtained by the indentation show a tendency to be tensile when the substrate is reached and decrease to values approximately equal to zero approaching the core. The results can be explained by considering the following: during cooling, the shrinkage of the substrate prevails in the system, which submits the $\mathrm{Fe}_{2} \mathrm{~B}$

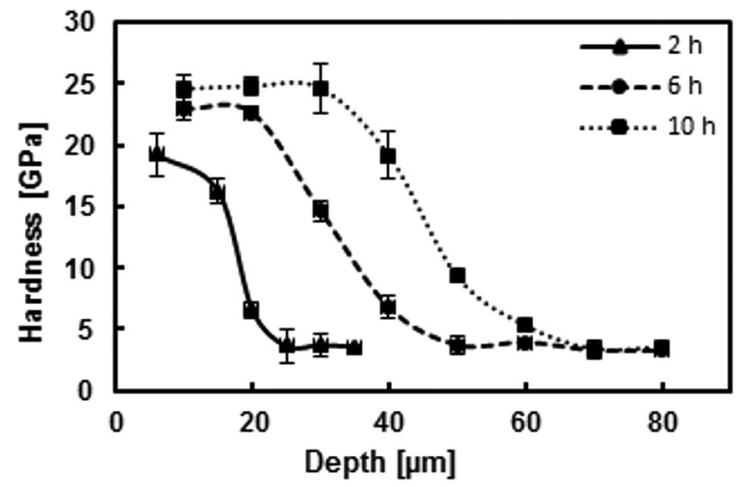

Figure 5. Hardness profile along the boride layer formed on AISI 304 steel at $1223 \mathrm{~K}$. Indentation load of $50 \mathrm{mN}$ with a Berkovich indenter.

phase $\left(7.85 \times 10^{-6}{ }^{\circ} \mathrm{C}^{-1}\right)$ to compressive stresses since the coefficient of thermal expansion of the substrate is greater $\left(18 \times 10^{-6}{ }^{\circ} \mathrm{C}^{-1}\right)$. The same applies between the $\mathrm{FeB}$ and $\mathrm{Fe}_{2} \mathrm{~B}$ phase, where the thermal expansion coefficient of the former is $23 \times 10^{-6}{ }^{\circ} \mathrm{C}^{-1}$, resulting in a selft-equilibrating stress state $^{23}$. In fact, the residual stresses in coating are mainly caused by lattice spacing and thermal expansion mismatch between the coating and substrate ${ }^{13}$.

\subsection{Adhesion test}

\subsubsection{Daimler-Benz adhesion test}

Inspection of the indentation conducted in the borided surface at 2, 6 and $10 \mathrm{~h}$ of exposure times show HF3, HF4 and HF5 adhesion quality respectively. It suggests that at higher exposures times, the system adhesion decreases. The high shear stresses caused by the applied load and indenter geometry are better supported by thin layer thickness formed $2 \mathrm{~h}$ of exposure time. In Figure 7a, b a poor delamination and some radial cracks are shown denoting an acceptable adhesion corresponding to 2 and $6 \mathrm{~h}$, respectively. At $10 \mathrm{~h}$ of exposure time, the Figure $7 \mathrm{c}$ depicts an extended delamination at the vicinity of the indentation evidencing a poor interfacial 
adhesion of boride layer due to the brittleness and high residual tensile stresses obtained in the FeB phase, causing susceptibility to failure when mechanical strain is applied. The foregoing is confirmed by Taktak et al. ${ }^{9}$, who concluded that adhesion increases at low boriding temperatures $(1073 \mathrm{~K})$, whereas at higher temperature $(1223 \mathrm{~K})$ adhesion is reduced in borided AISI 304 and H13 steels. Moreover, G. RodriguezCastro et al. ${ }^{14}$ evaluated the adhesion of borides layers on AISI 1045 steel where only saw-tooth morphology $\mathrm{Fe}_{2} \mathrm{~B}$ is formed. The results demonstrated radial cracks around the

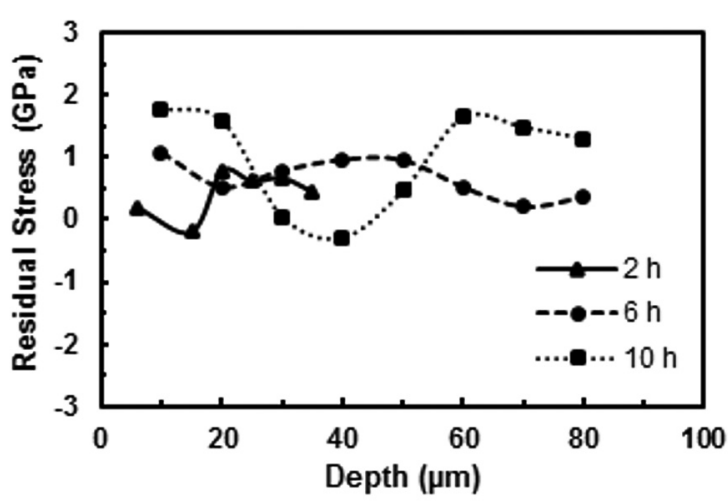

Figure 6. Residual stresses obtained by indentation using the Chen equation ${ }^{11}$ in $\mathrm{FeB}$ and $\mathrm{Fe}_{2} \mathrm{~B}$ phases formed on AISI 304 steel. indentation mark indicating brittleness but good adhesion to the substrate corresponding to a HF3 quality adhesion.

\subsubsection{Scratch tests}

Scratch tests were carried out to determine the damage mechanisms and critical loads of the borides layers produced on AISI 304 steel. For the three boriding conditions, as the load applied increases, the friction coefficient $(\mathrm{CoF})$ increases to a maximum value of approximately 0.45 . The slope changes in the $\mathrm{CoF}$ are correlated with the occurrence of damage and are depicted in Figures 8a, 9a and 10a for 2, 6 and $10 \mathrm{~h}$, respectively. For $2 \mathrm{~h}$ of exposure time occur the following damage mechanisms: in Figure $8 \mathrm{~b}$ depicts the hertzian cracking (A) occurred in the boride layer reflecting the coating brittleness. Tensile stress at the periphery of the indenter generates a ring-shaped crack which propagates from the surface toward the substrate; several of these rings are formed, and they come to overlap and form a network along the boride layer in the scratch, forming hertzian craks. Furthermore, Figure 8b shows the chipping (B) of boride layer that is characterized by separating a part of the FeB phase to minimize the amount of stored elastic energy by the compressive stress generated in front of the indenter during testing $^{24}$. In Figure 8c, the cracks formed on the sides of the scratch (C) are due to the plastic deformation of the substrate which has a major effect on small thicknesses, in this case it corresponds to $13 \mu \mathrm{m}$ ( $2 \mathrm{~h}$ of exposure time). In addition, the tensile cracks (D) are formed by the recovery of the cracks

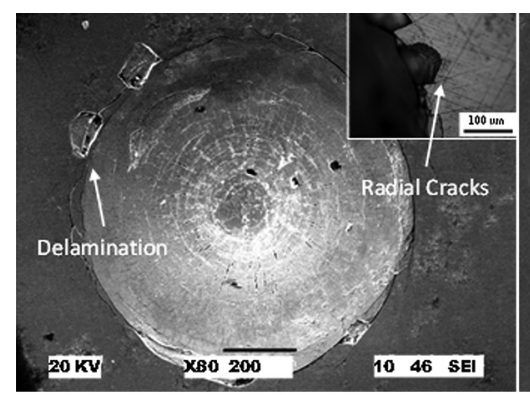

(a)

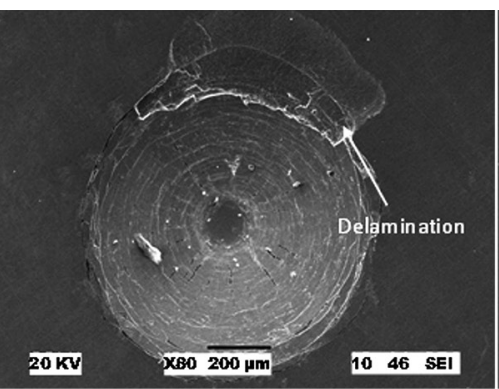

(b)

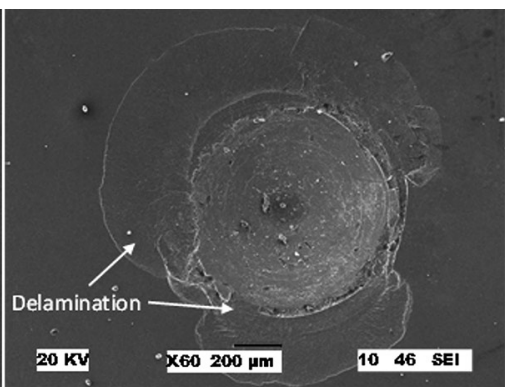

(c)

Figure 7. SEM micrographs of Daimler-Benz adhesion test on AISI 304 steel borided at $1223 \mathrm{~K}$ and different exposure times: (a) 2 h, (b) $6 \mathrm{~h}$ and (c) $10 \mathrm{~h}$.

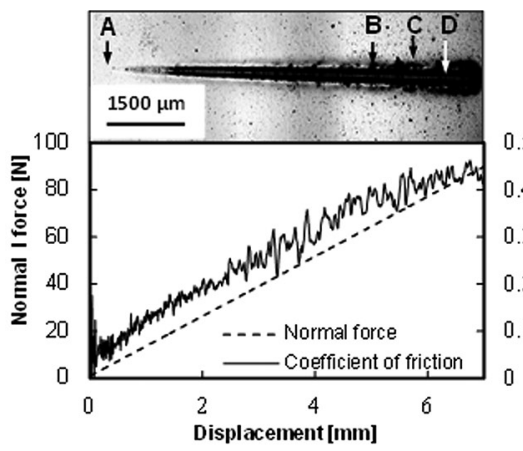

(a)

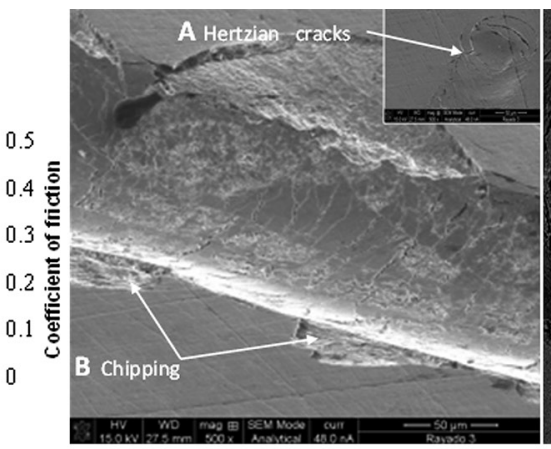

(b)

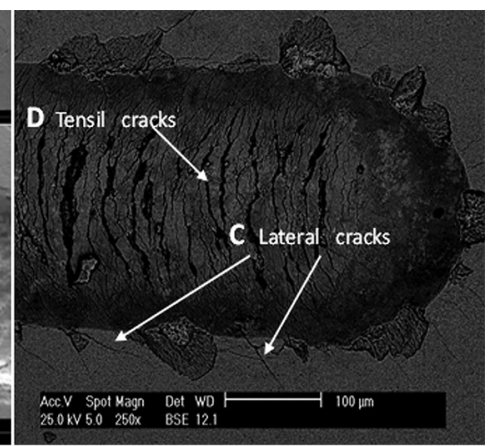

(c)

Figure 8. SEM micrographs of scratch test on AISI 304 borided steel at $1223 \mathrm{~K}$ during $2 \mathrm{~h}$ of exposure time: (a) Correlation between $\mathrm{CoF}$ and occurrence of damage, (b) hertzian and chipping mechanism, (c) lateral and tensil cracks. 


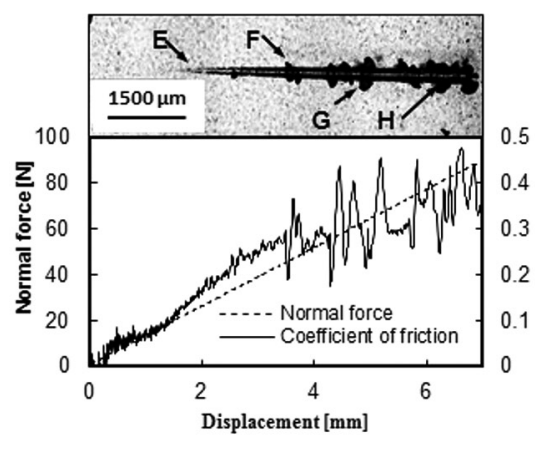

(a)

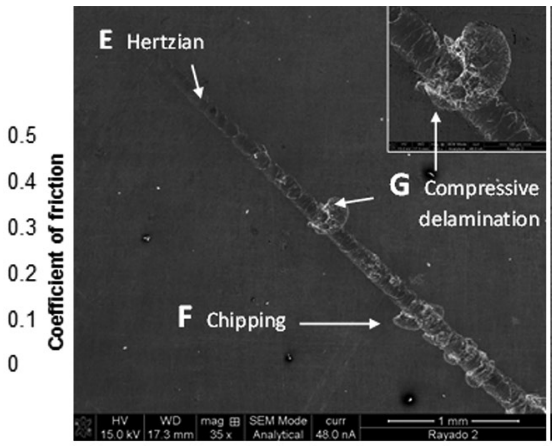

(b)

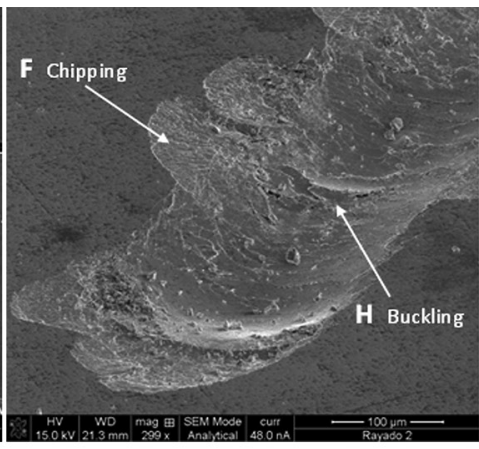

(c)

Figure 9. SEM micrographs of scratch test on AISI 304 steel borided at $1223 \mathrm{~K}$ during 6 h of exposure time: (a) Correlation between CoF and occurrence of damage, (b) Hertzian, chipping and compressive delamination mechanisms, (c) Chipping and buckling mechanisms.

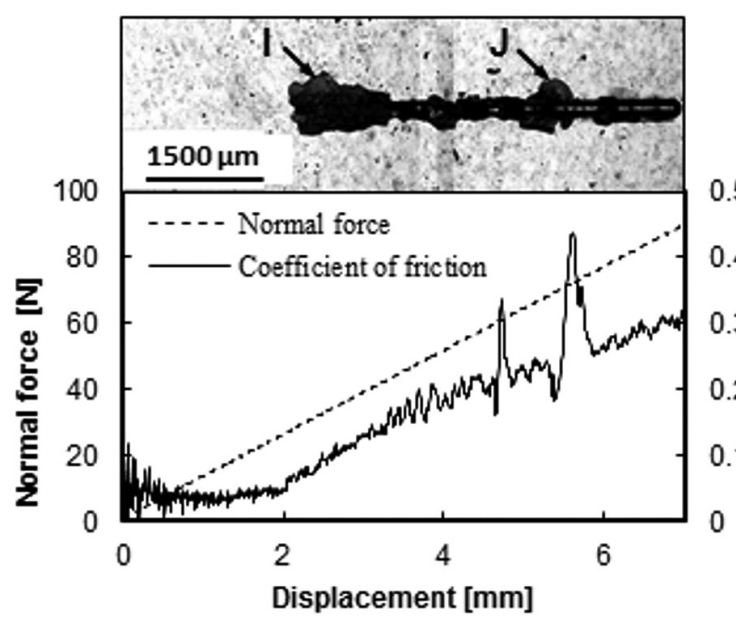

(a)

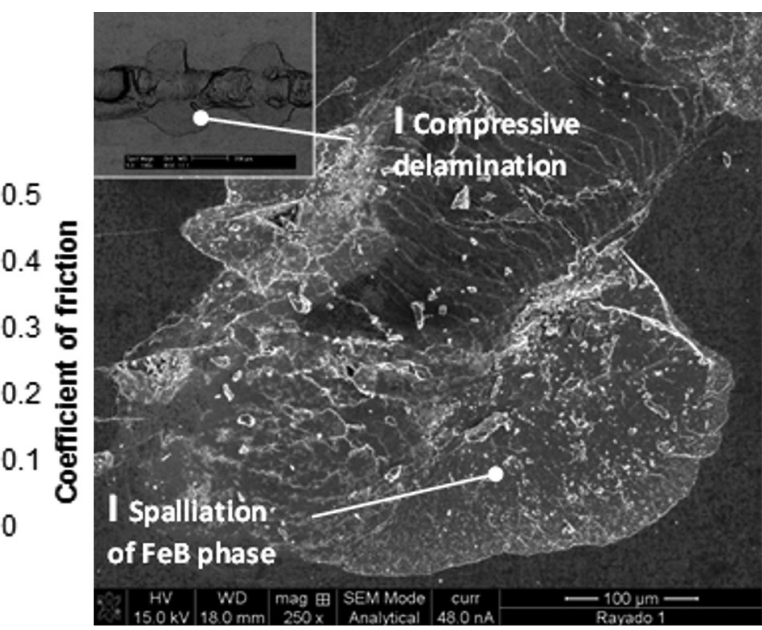

(b)

Figure 10. SEM micrographs of scratch test on AISI 304 steel borided at $1223 \mathrm{~K}$ during $10 \mathrm{~h}$ of exposure time: (a) Correlation between $\mathrm{CoF}$ and occurrence of damage, (b) Spalliation and compressive delamination mechanisms.

Table 1. Critical loads and failures mechanisms produced by scratch test on AISI 304 steel borided at $1223 \mathrm{~K}$.

\begin{tabular}{ccrc}
\hline Exposure time & \multicolumn{2}{c}{ Critical load } & Mechanisms \\
\hline \multirow{2}{*}{$2 \mathrm{~h}$} & $\mathrm{Lc}_{1}$ & $8.6 \pm 0.3$ & Hertzian crack \\
& $\mathrm{Lc}_{2}$ & $35.6 \pm 2.4$ & Chipping \\
& $\mathrm{Lc}_{1}$ & $17.3 \pm 1.0$ & Hertzian crack \\
$6 \mathrm{~h}$ & $\mathrm{Lc}_{2}$ & $43.4 \pm 0.8$ & Chipping \\
& $\mathrm{Lc}_{3}$ & $27.5 \pm 1.0$ & Spalling \\
\hline
\end{tabular}

to the passage indenter. In Figure 9 which corresponds to $6 \mathrm{~h}$ of exposure time of boriding, the plastic deformation of the substrate diminishes and the presence of hertzian cracking (E) is apparent. The chipping areas of the FeB phase are larger (F). Also, Figure $9 \mathrm{~b}$ depicts compressive delamination of $\mathrm{FeB}(\mathrm{G})$ that is generated to release the stored elastic energy during passage of the indenter evidenced by a semicircular delamination propagating outside the scratch. Buckling $(\mathrm{H})$ is noted inside the scratch track which is induced by opposite tangential force of the coating in response to the compressive stress generated in front of the indenter. Figure $10 \mathrm{~b}$ shows the damage mechanisms found in $10 \mathrm{~h}$ of exposure time corresponding to compressive delamination $(\mathrm{J})$ and spalling of $\mathrm{FeB}$ phase (I), on average. The tensile residual stresses promote the crack growth in the $\mathrm{FeB} / \mathrm{Fe}_{2} \mathrm{~B}$ interface during $10 \mathrm{~h}$ of treatment denoting low adhesion. Damage mechanisms are strongly influenced by the residual stress and fracture toughness of the FeB phase promoting cracking and chipping giving preference to cohesive failure rather than adhesive in the layer/substrate interface. Table 1 summarizes the critical loads for specific, defined and repeatable damage mechanisms for AISI 304 borided steel. Critical loads for Hertzian cracking and chipping in $6 \mathrm{~h}$ are greater than $2 \mathrm{~h}$; loads are increased by 50 and $17 \%$, respectively. For 10 hours, the spallation mechanism occurs at 27 N. Spallation is more severe with a lower critical load that chipping occurred at $6 \mathrm{~h}$. Therefore, treatment to $6 \mathrm{~h}$ offers the best performance in the scratch test. Critical loads determined in iron borides formed on AISI 304 steel are lower compared to the work of Alloui et al. ${ }^{8}$ who borided XC38 steel.

The effects of the alloying elements of AISI 304 steel (chromium and nickel) play an important role in the 
coating/substrate failure. First, the boride layer is composed by solid solutions (Fe, M) B and (Fe, M ${ }_{2} \mathrm{~B}$ formed by partial substitution of iron with metallic atoms as chromium and nickel. The chromium can increases the hardness and brittleness ${ }^{25}$ and promote cracking and eventual cohesive/adhesive failure during the pass of indenter in the scratch test. Second, the saw-tooth interface morphology is reduced due to $\mathrm{Cr}$ and $\mathrm{Ni}$ elements compared of low carbon steels, causing the adherence between the phases to decrease. Third, the magnitude of the tensile residual stresses promotes crack growth coupled with the low fracture toughness of the FeB phase whose value fell within the range of 1.48-3.02 $\mathrm{MPa} \sqrt{m}^{[26]}$ causing the early onset of cohesive damage. The mechanisms of damage and determined critical loads are particular cases of each layer/substrate system. The damage of hard coatings in adhesion tests depends on a combination of elastic and fracture properties of coating/substrate system such as pores, flaws, loading conditions, fracture toughness, frictional performance, counterpart material, etc.

\section{Conclusions}

In this study, the boriding of 304 steel was successfully carried out by a power pack process. The surface compound is formed by a bi-layer system $\left(\mathrm{FeB}+\mathrm{Fe}_{2} \mathrm{~B}\right)$. Alloying

\section{References}

1. Rickerby D. Measurement of coating adhesion. In: Stern KH, editor. Metallurgical and ceramic protective coatings. London: Chapman \& Hall; 1996. p. 306.

2. Rodríguez-Castro G, Campos-Silva I, Chávez-Gutiérrez E, Martínez-Trinidad J, Hernández-Sánchez E and Torres-Hernández A. Mechanical properties of FeB and Fe2B layers estimated by Berkovich nanoindentation on tool borided steels. Surface and Coatings Technology. 2013; 215:291-299. http://dx.doi. org/10.1016/j.surfcoat.2012.05.145.

3. Campos I, Ramírez G, Villa Velázquez C, Figueroa U and Rodríguez G. Study of microcracks morphology produced by Vickers indentation on AISI 1045 borided steels. Materials Science and Engineering. 2008; 475(1-2):285-292. http:// dx.doi.org/10.1016/j.msea.2007.04.052.

4. American Society for Metals - ASM. ASM Handbook: heat treating. Ohio: ASM; 1991. v. 4. 437 p.

5. Matuschka A. Boronizing. Germany: Carl Hanser Verlag; 1980.

6. Meléndez E, Campos I, Rocha E and Barrón MA. Structural and strength characterization of steels subjected to boriding thermochemical process. Materials Science and Engineering. 1997; 234-236:900-903. http://dx.doi.org/10.1016/S09215093(97)00389-4.

7. Eyre TS. Effect of boronising on friction and wear of ferrous metals. Wear. 1975; 34(3):383-397. http://dx.doi.org/10.1016/00431648(75)90105-2.

8. Allaoui O, Bouaouadja N and Saindernan G. Characterization of boronized layers on a XC38 steel. Surface and Coatings Technology. 2006; 201(6):3475-3482. http://dx.doi.org/10.1016/j. surfcoat.2006.07.238.

9. Taktak S. Some mechanical properties of borided AISI H13 and 304 steels. Materials \& Design. 2007; 28(6):1836-1843. http://dx.doi.org/10.1016/j.matdes.2006.04.017. elements decrease the growth rate of borides causing a less rough interface. The hardness determined boride layers show a high hardness compared to other treatments such as nitriding and carburizing, for example. According to Daimler-Benz adhesion test, for 2 and $6 \mathrm{~h}$ of exposure times, the adhesion quality is acceptable. But for $10 \mathrm{~h}$ it is insufficient, with a pattern of HF5. The scratch tests performed on specimens subjected to 2 and $6 \mathrm{~h}$ of treatment caused cohesive failures of $\mathrm{FeB}$ phase. $\mathrm{A} 10 \mathrm{~h}$ of exposure, the most evident mechanism is gross spalling of the FeB phase and its critical load is low. According to these results, Treatment for $6 \mathrm{~h}$ has the best performance under these test conditions, because it has higher values of critical loads, less severe damage mechanisms and smoothed residual stress profile. The presence of $\mathrm{FeB} / \mathrm{Fe} 2 \mathrm{~B}$ system promotes cracking and cohesive damage of $\mathrm{FeB}$ reducing the scratch resistance of AISI 304 borided steel.

\section{Acknowledgements}

This work was supported by research grants SIPSNI-2011/15, 20150047 and 20151312 of Instituto Politécnico Nacional and 183836 from the National Council of Science and Technology.
10. International Organization for Standardization - ISO. ISO 14577-1: metallic materials: instrumented indentation test for hardness and materials parameters. Part 1: test method. Geneva: ISO; 2002.

11. Oliver WC and Pharr GM. An improve technique for determining hardeness and elastic modulus using load and displacement sensing indentation experiments. Journal of Materials Research. 1992; 7(6):1564-1583. http://dx.doi.org/10.1557/JMR.1992.1564.

12. Yan J, Karlsson AM and Chen X. Determining plastic properties of a material with residual stress by using conical indentation. International Journal of Solids and Structures. 2007; 44(1112):3720-3737. http://dx.doi.org/10.1016/j.ijsolstr.2006.10.017.

13. Chen KS, Chen TC and Ou KS. Development of semiempirical formulation for extracting materials properties from nanoindentation measurements: Residual stresses, substrate effect, and creep. Thin Solid Films. 2008; 516(8):1931-1938. http://dx.doi.org/10.1016/j.tsf.2007.09.005.

14. Rodríguez-Castro G, Campos-Silva I, Martínez-Trinidad J, Figueroa-López U, Meléndez-Morales D and Vargas-Hernández J. Effect of boriding on the mechanical properties of AISI 1045 steel. Advanced Materials Research. 2009; 65:63-68. http:// dx.doi.org/10.4028/www.scientific.net/AMR.65.63.

15. Verein Deutscher Ingenieure Normen - VDI. VDI 3198: coating (CVD, PVD) of cold forging tools. Dusseldorf: VDI-Verlag; 1991.

16. Vidakis N, Antoniadis A and Bilalis N. The VDI 3198 indentation test evaluation of a reliable qualitative control for layered compounds. Journal of Materials Processing Technology. 2003; 143-144:481-485. http://dx.doi.org/10.1016/S09240136(03)00300-5.

17. American Society for Testing and Materials - ASTM. ASTM C1624-2005: standard test method for adhesion strength and mechanical failure modes of ceramic coatings by quantitative single point scratch testing. West Conshohocken: ASTM; 2005. 
18. Rus J, Leal CL and Tsipas DN. Boronizing of 304 Steel. Journal of Materials Science Letters. 1985; 4(5):558-560. http://dx.doi. org/10.1007/BF00720032.

19. Martini C, Palombarini G and Carbucicchio M. Mechanism of thermochemical growth of iron borides on iron. Journal of Materials Science. 2004; 39(3):933-937. http://dx.doi. org/10.1023/B:JMSC.0000012924.74578.87.

20. Badini C, Gianoglio C and Pradelli G. The effect of carbon, chromium an nickel on the hardness of borided layers. Surface and Coatings Technology. 1987; 30(2):157-170. http://dx.doi. org/10.1016/0257-8972(87)90140-X.

21. Badini C, Gianoglio C and Pradelli G. Distribution of chromium and nickel between the phases present in the borided layer of alloy steels. Metallurgical Science and Technology. 1985; 3:10-15.

22. Campos I, Farah M, López N, Bermúdez G, Rodríguez G and Villa Velázquez C. Evaluation of the tool life and fracture toughness of cutting tools boronized by the paste boriding process. Applied Surface Science. 2008; 254(10):2967-2974. http://dx.doi.org/10.1016/j.apsusc.2007.10.038.
23. Campos-Silva I, Martínez-Trinidad J, Doñu-Ruíz MA, Rodríguez-Castro G, Hernández-Sánchez E and Bravo-Bárcenas O. Interfacial indentation test of $\mathrm{FeB} / \mathrm{Fe} 2 \mathrm{~B}$ coatings. Surface and Coatings Technology. 2011; 206(7):1809-1815. http:// dx.doi.org/10.1016/j.surfcoat.2011.08.017.

24. Rickerby DS. A review of the methods for the measurement of coating-substrate adhesión. Surface and Coatings Technology. 1988; 36(1-2):541-557. http://dx.doi.org/10.1016/02578972(88)90181-8.

25. Carbucicchio M, Meazza G and Palombarini G. Surface structure of boride layers grown on Fe-C-Ni alloys. Journal of Materials Science. 1982; 17(11):3123-3128. http://dx.doi.org/10.1007/ BF01203474.

26. Hernández-Sanchez E, Rodriguez-Castro G, Meneses-Amador A, Bravo-Bárcenas D, Arzate-Vazquez I, Martínez-Gutiérrez $\mathrm{H}$, et al. Effect of the anisotropic growth on the fracture toughness measurements obtained in the Fe2B layer. Surface and Coatings Technology. 2013; 237:292-298. http://dx.doi. org/10.1016/j.surfcoat.2013.09.064. 